\title{
La-Related Protein 4B
}

National Cancer Institute

\section{Source}

National Cancer Institute. La-Related Protein 4B. NCI Thesaurus. Code C143066.

La-related protein 4B (738 aa, $~ 81 \mathrm{kDa}$ ) is encoded by the human LARP4B gene. This protein is involved in the positive regulation of translation. 